\title{
Properties of Standard Polymeric and Water-Based Coatings for Military Camouflage Protection with Addition of Inorganic Fulerene- Like Tungsten Disulphide (IF-WS $)_{2}$ Nanoparticles
}

\author{
Dragana Lazić ${ }^{1)}$ \\ Danica Simić ${ }^{1)}$ \\ Aleksandra Samolov ${ }^{1)}$ \\ Desimir Jovanovićc ${ }^{2)}$
}

\begin{abstract}
The possibility of improving the properties of the standard polymeric and a water-based coating for military camouflage protection by adding nanoparticles of inorganic fulerene-like tungsten disulphide (IF-WS $)_{2}$ ). Nanoparticles were added and dispersed in paint by ultrasonic irradiation. The paints were applied to standard steel plates, and dried, for examinations of chemical resistance to agressive media and of the following physical-mechanical properties: hardness, flexibility, elasticity, abrasion resistance, resistance to steel balls impact and adherence. These properties were compared for paint without and with IF-WS 2 nanoparticles. The effect of adding IF-WS 2 on rheological properties of the paints has been examined using Dynamic Mechanical Analysis (DMA), observing viscosity as a function of the shear rate. Camouflage properties were also examined - IR reflection and colorimetry. Significant improvements of mechanical resistance to abrasion and steel balls impact, as well as hardness, have been achieved
\end{abstract}

Key words: coating, protection coating, polymeric coating, water based coating, tungsten disulfide, nanoparticles, camouflage, camouflage protection, military application.

\section{Introduction}

$\mathrm{C}$ OATINGS are mainly used for decorative, protective or functional purposes, but the combination of all is the most common in coatings application. When we talk about the functionality of one coating system, the term functional refers to a certain ability of the coating, such as self-cleaning, easyto-clean, antifouling, antibacterial and anti-flammable features [1]. Another functional characteristic of one coating system may be camouflage protection.

Nanomaterials, having high surface area, are proven to enhance physical, chemical, mechanical, optical and magnetic properties of materials in which they are added, which can result in exploitation of a variety of structural and nonstructural application. Different nanoparticles can be used as fillers in paints for improving their wear-resistance, erosionresistance and corrosion resistance [2].

Transition-metal dichalcogenides ( $\mathrm{MoS}_{2}, \mathrm{WS}_{2}, \mathrm{NbS}_{2}$, etc.), due to their excellent mechanical properties, are used for a wide range of applications, including aerospace and automotive technology, load bearing and release mechanisms, as solid lubricants, corrosion protection etc [3-10]. In the form of inorganic fullerene-like particles, with unique morphology, spherical and closed structure, they possess a chemical inertness and a high elasticity. Due to these exceptional characteristics, inorganic fullerene-like particles, such as tungsten disulfide $\mathrm{IF}_{-} \mathrm{WS}_{2}$, are recognized as promising materials and promising fillers of the composites and are extensively studied for their ability to control wetting, adhesion, lubrication on surfaces and interfaces, and to achieve good corrosion protection and wear resistance, thus, they may be used as an addition for different types of protective coatings [11-13].

Spectrophotometric measurements are wildly spread in characterization of dyes whether it measured their absorbance, reflectance or other properties [14], whether we use this dyes for colouring metals or textiles [15]. These measurements can give us valuable information regarding colour coordinates of dyes as well, which are their main characteristics, especially when it comes to military camouflage paint. Incident radiation is reflected or both reflected and refracted at a coating surface. Both reflection and refraction are dependent on the refractive indices of the two media. A description of the mirror-like reflection or specular reflection at the surface of the coating is termed gloss, as distinct from the reflectance of the coating which is also dependent on pigments and fillers in the coating [16]. Specular reflection is strongly increased by leafing pigments such as metal flakes. Gloss is principally dependent on the angle of incidence and the smoothness of the surface, being high for smooth surfaces and low for irregular surfaces. Infrared radiation entering a paint coating is refracted at the interface before encountering the pigment and filler particles. The radiation is partially reflected and partially refracted at the surfaces of these particles and in normal pigmented paints the process of multiple reflection and refraction thoroughly

\footnotetext{
1) Military Technical Institute (VTI), Ratka Resanovića 1, 11132 Belgrade, SERBIA

2) Zastava Arms, Kosovska 4, 34000 Kragujevac, SERBIA

Correspondence to: lazicdragana85@gmail.com
} 
diffuses the beam. A proportion of this radiation propagates back to the coating surface where it leaves in all directions. Diffusion of radiation arises from a large number of essentially random scattering events and the overall diffusion process is simply termed "scattering" [16].

In this paper, the possibility of using IF-WS ${ }_{2}$ nanoparticles as a filler in a two-component black polyurethane coating (PUR black) and in a two-component water-based dark green paint (PUR dark green) for military camouflage protection is examined and the properties of paints with and without nanoparticles were compared and analyzed, regarding the requirements of military standards concerning paint coatings. Water-based paints have low VOC (volatile organic compound) concentration, so they are eco-friendly substitute for common polymeric coatings, which is very important nowadays for their further usage. Moreover, an accent has been put on the examination of mechanical and chemical resistance of these paints, having in mind that this kind of coatings are often used in severe conditions of exploitation (Figure 1). In the end, the effect of IF-WS ${ }_{2}$ nanoparticles on spectrophotometric properties, i.e. on the camouflage ability of paints is examined. All the experimental procedures were carried out in the Military Technical Institute in Belgrade, Department for Materials and Protection.

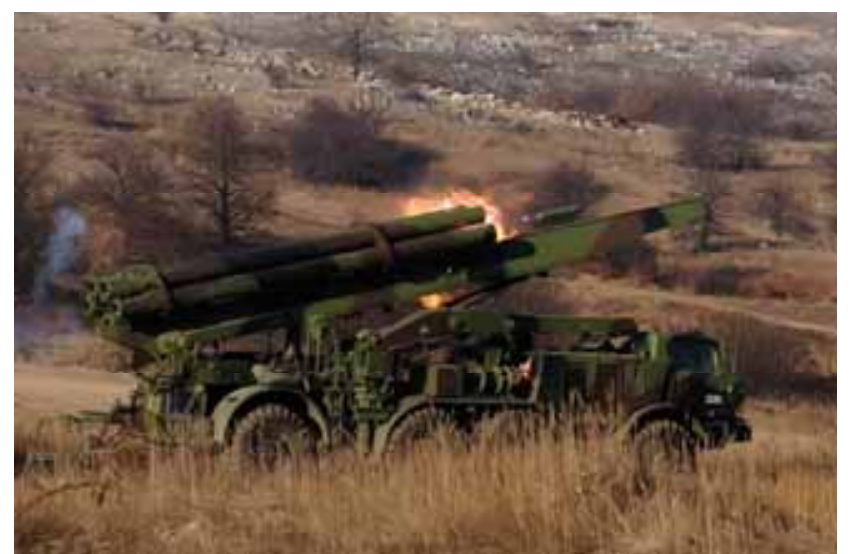

Figure 1. An example of severe exploitation conditions for a camouflage paint on a combat vehicle

\section{Materials and experimental procedure}

Inorganic fullerene-like tungsten disulphide nanoparticles $\left(\mathrm{NanoLub}^{\mathrm{TM}}, \mathrm{d}_{25^{\circ} \mathrm{C}} \sim 7.5 \mathrm{~g} / \mathrm{cm}^{3}\right.$ ) were added into the standard polymeric and a water-based coatings for military camouflage protection. Two-component polyurethane paints from the manufacturer PITURA, Belgrade, were used. For PUR black, the added concentration of nanoparticles was $1 \mathrm{wt} . \%$, and for PUR dark green, the concentration was $0.5 \mathrm{wt} . \%$.

After adding nanoparticles to isocyanate component of the paint, dispersion and particle deagglomeration were performed at the room temperature:

- for PUR black - in ultrasonic bath for $45 \mathrm{~min}$ at the room temperature,

- for PUR dark green - using ultrasonic processor Badelin SonoPuls, at $50 \mathrm{~W}$ of power, during $30 \mathrm{~min}$.

After nanoparticles deagglomeration, both components of the paint were homogenized on a mechanical stirrer during 30 min, and then paints were directly applied onto steel plates in thickness of a layer approximately 50 microns, and left to dry and cure during 24 hours at the room temperature (Fig.2). Prior to painting, the plates were previously prepared: abraded using SiC paper to 120 grit and cleaned with acetone. The number and size of the steel plates are taken according to relevant military standards for examinations of military camouflage paints.

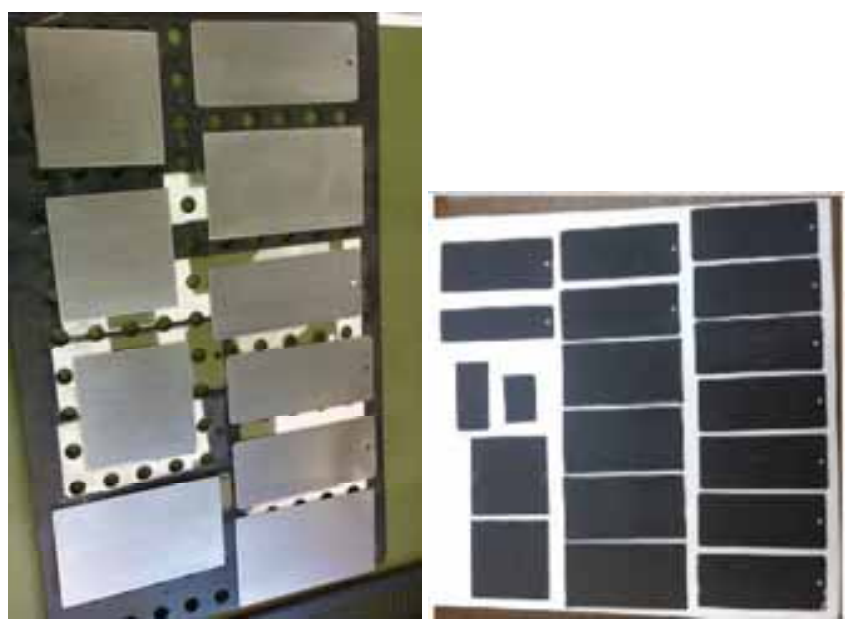

Figure 2. Prepared surface of the test plates and applied paint PUR black

\section{Physical-mechanical testing}

The examined paints with and without nanoparticles of IF$\mathrm{WS}_{2}$ were tested according to military stadards SORS 1564 (for standard polymer coatings), SORS 9404/15 (for waterbased coatings) and SORS 1634/03 [17-19]. The following properties were determined and analyzed:

- Adherence-cross-cut test, using Elcometer device according to SRPS EN ISO 2409 [20],

- Elasticity - cupping test, using Erichsen 202 device, according to SRPS EN ISO 1520 [21],

- Hardness, according to König, Erichsen 399,

- Resistance to steel balls impact, using Erichsen 273 D device (Fig.3a),

- Flexibility - bend test (cylindrical mandrel), using Erichsen 266 device, according to SRPS EN ISO 1519 [22],

- Abrasion resistance, using Erichsen 251/I device (Fig.3b).

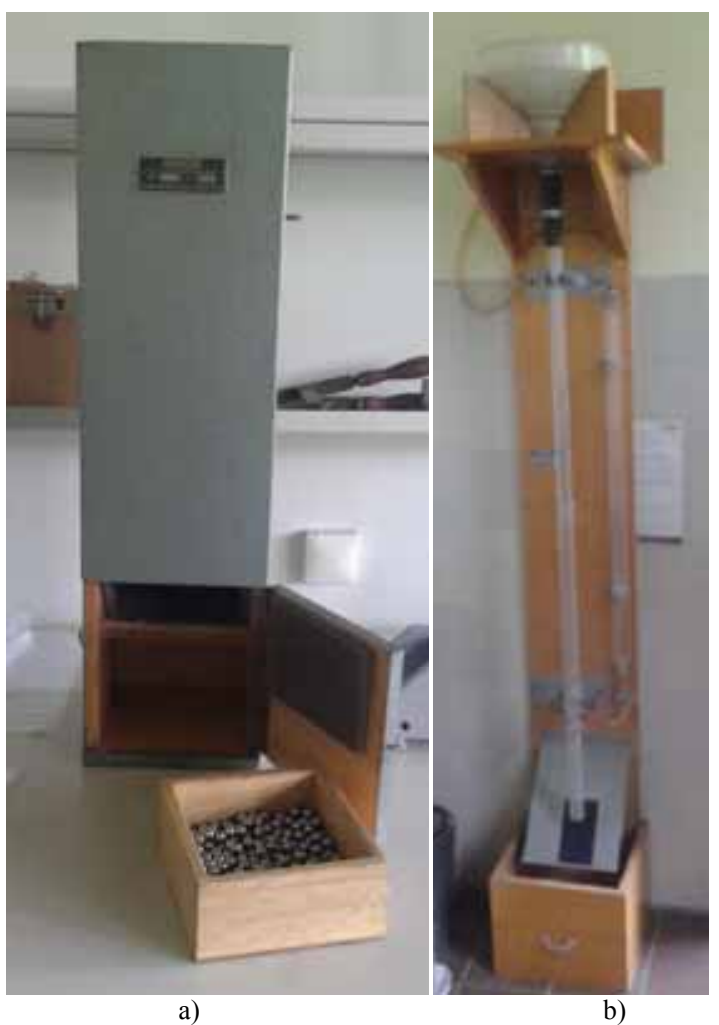

Figure 3. Erichsen 273 D device for test of resistance to steel balls impact (a), and Erichsen 251/I device for abrasion resistance test (b) 


\section{Resistance to aggressive media}

The persistance of the examined camouflage paints in different aggressive media is tested. The steel plates with the paints applied were immersed in different liquids and dried afterwards. The liquids were:

- water

- sodium-chloride water solution (3.5 wt.\%),

- hydrocarbons mixture ( $80 \mathrm{vol} . \%$ of isooctane and $20 \mathrm{vol} . \%$ of benzene),

- mineral oil (according to JUS TP.9 standard [23]).

After required time in all these media, the steel plates were taken out, dried and observed in order to compare the appearence of the coatings after the exposure to agressive solutions.

\section{Rheological behavior analysis}

Dynamic mechanical analysis (DMA) of the investigated samples were performed using the Modular Compact Rheometer MCR-302 (Anton Paar GmbH) [24], equipped with paralel plate fixtures for testing liquid samples (Fig.4). The DMA tests, in order to evaluate the rheological properties of the tested paints, have included test of sheer stress dependence on shear rate and determination of viscosity $(\eta)$. Tests were performed at a chosen frequency of $1 \mathrm{~Hz}$ at the ambient temperature, which was approximately $20^{\circ} \mathrm{C}$.

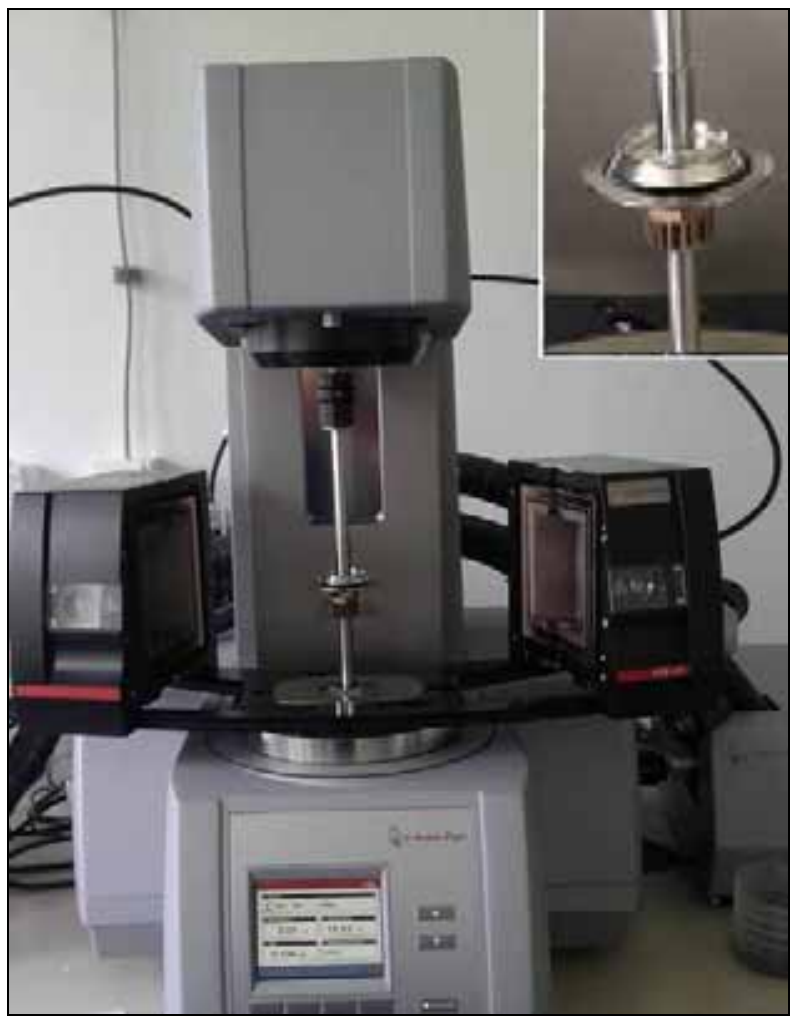

Figure 4. The Modular Compact Rheometer MCR-302

\section{Camouflage properties - IR reflection and colorimetry}

The spectrophotometric measurements were conducted using the UV/VIS/NIR spectrophotometer UV 3600 from a Japanese manufacturer Shimadzu with an integrating sphere [25]. The reflectance was measured in the visible and nearinfrared area of the electromagnetic spectrum $(650-1000 \mathrm{~nm})$ using UV Probe programme package, while colour coordinates were measured in visible part of the electromagnetic spectrum $(380-780 \mathrm{~nm})$ using Colour programme package with $10^{\circ}$ and D65 observer [25].

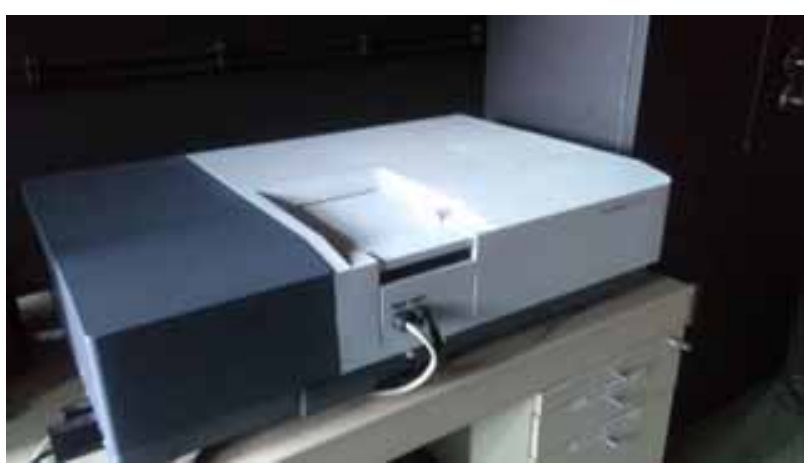

Figure 5. The Shimadzu UV/VIS/NIR spectrophotometer UV 3600

\section{Results and discussion}

\section{Physical-mechanical properties}

The comparative examinations results of PUR black and PUR dark green with and without IF-WS 2 according to the military standards are presented in Table 1.

Table 1. Results of the physical-mechanical examinations

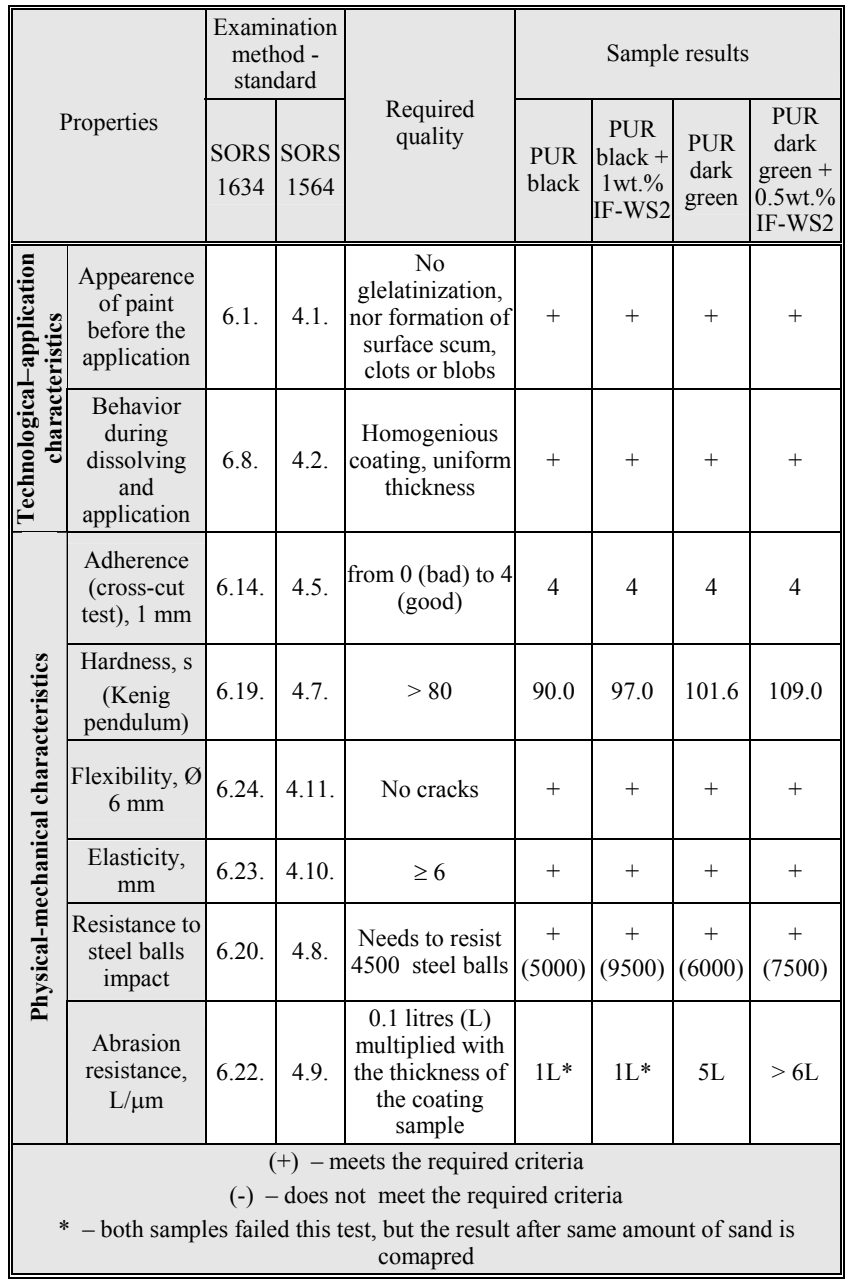

It may be observed that both paints, with and without nanoparticles, have good technological - application characteristics. Regarding the physical-mechanical resistance, the sample containing nanofiller has improved behaviour. Adherence, elasticity and flexibility of both samples have met the requirements of the standards.

Hardness is a superior for the sample containing IF-WS 2 . Resistance to steel balls impact was far better for the sample with nanoparticles. According to the standard, it is necessary 
that the coating applied on a steel plate resists the impact of 4500 steel balls, and, as shown in the table, PUR black with nanoparticles resisted the impact of 9500 balls - twice as much as the sample without nanoparticles. PUR dark green resisted the impact of 7500 balls.

Abrasion resistance is tested using a defined granulation of sand falling from defined height. The amount of sand for each coating sample is defined regarding the thickness of the tested coating, as litres of sand per layer thickness, multiplied with 0.1. In this research, for PUR black paint, both samples have failed, but for the comparison, the appearances of the samples after the same amount of sand are taken (after 1 litre of sand). It has been shown that the sample with nanoparticles has better abrasion resistance, and Fig.6 ( $a$ and $b$ ) illustrates this. The fact that both tested samples have failed this test may be a consequence of the paint layer thickness. For PUR dark green the samples with IF-WS $\mathrm{W}_{2}$ also have shown better abrasion resistance, although both samples have met the required criteria of the standard. Fig.6 (c and d) shows the appearance of the samples with and without nanoparticles, after the same amount of sand. In this case, it is the amount of 5 litres of sand, after which the surface of the coating without nanoparticles has been degraded.
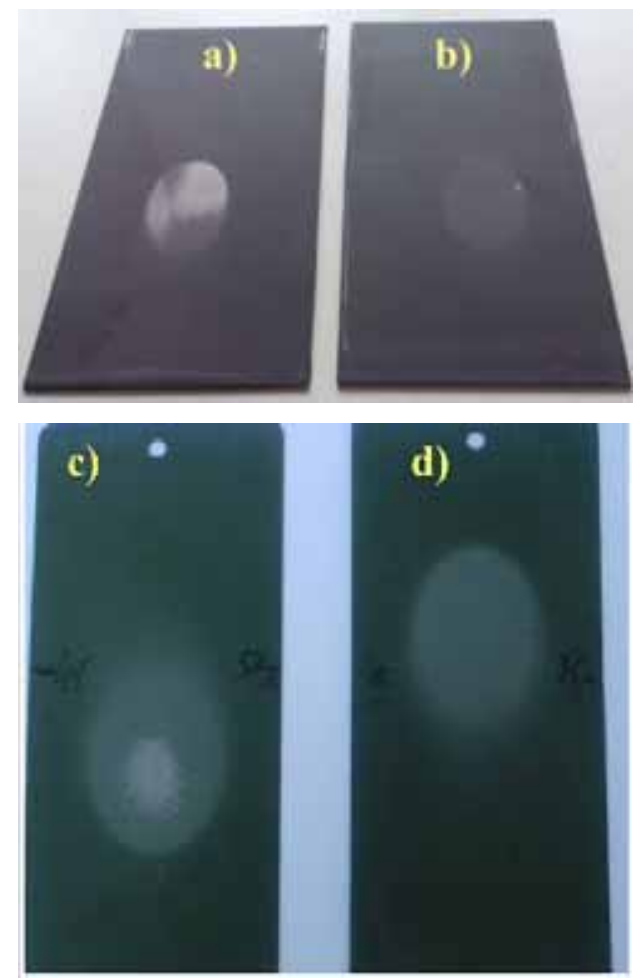

Figure 6. Abrasion resistance test: a) PUR black, b) PUR black + 1 wt.\% IF$\mathrm{WS}_{2}$, c) PUR dark green, d) PUR dark green $+0.5 \mathrm{wt} . \% \mathrm{IF}-\mathrm{WS}_{2}$

\section{Resistance to aggressive media}

Results of these examinations are given in the Table 2.

Table 2. Persistence of coatings in aggressive media

\begin{tabular}{||c|c|c|c|c|c|c||}
\hline \hline \multirow{2}{*}{$\begin{array}{c}\text { Agressive } \\
\text { medium }\end{array}$} & Methodology & $\begin{array}{c}\text { Examined } \\
\text { property/ } \\
\text { Criteria }\end{array}$ & $\begin{array}{c}\text { PUR } \\
\text { black }\end{array}$ & $\begin{array}{c}\text { PUR } \\
\text { black }+ \\
1 \mathrm{wt} \% \\
\text { IF-WS }\end{array}$ & $\begin{array}{c}\text { PUR } \\
\text { dark } \\
\text { green }\end{array}$ & $\begin{array}{c}\text { PUR dark } \\
\text { green + } \\
1 \text { Wt.\% IF- } \\
\mathrm{WS}_{2}\end{array}$ \\
\hline Water & $\begin{array}{c}\text { Immersion, } \\
\mathrm{t}=23 \pm 2{ }^{\circ} \mathrm{C}, \\
168 \mathrm{~h}\end{array}$ & $\begin{array}{c}\text { No changes in } \\
\text { appearance } \\
\text { and stickiness }\end{array}$ & + & + & + & + \\
\hline $\begin{array}{c}\text { Sodium- } \\
\text { chloride water } \\
\text { solution (3.5 } \\
\text { wt.\%) }\end{array}$ & $\begin{array}{c}\text { Immersion, } \\
\mathrm{t}=23 \pm 2{ }^{\circ} \mathrm{C}, \\
120 \mathrm{~h}\end{array}$ & & + & + & + & + \\
\hline
\end{tabular}

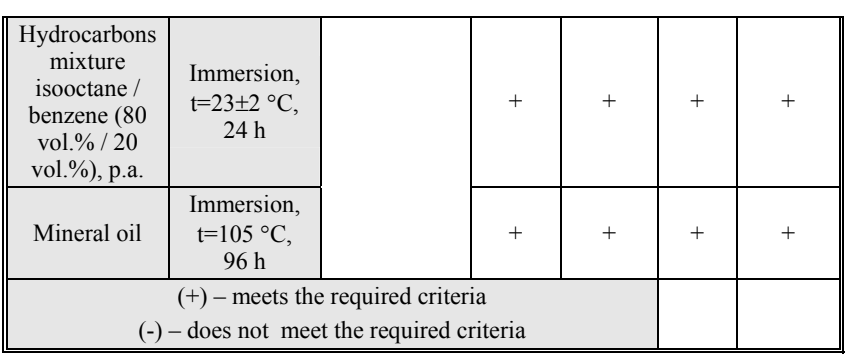

Both tested samples have met the criteria of the tests - the coatings are persistent in all the used agressive media.

\section{Rheological properties}

The results of DMA - curves of sheer stress as a function of shear rate, are presented in Fig.7.

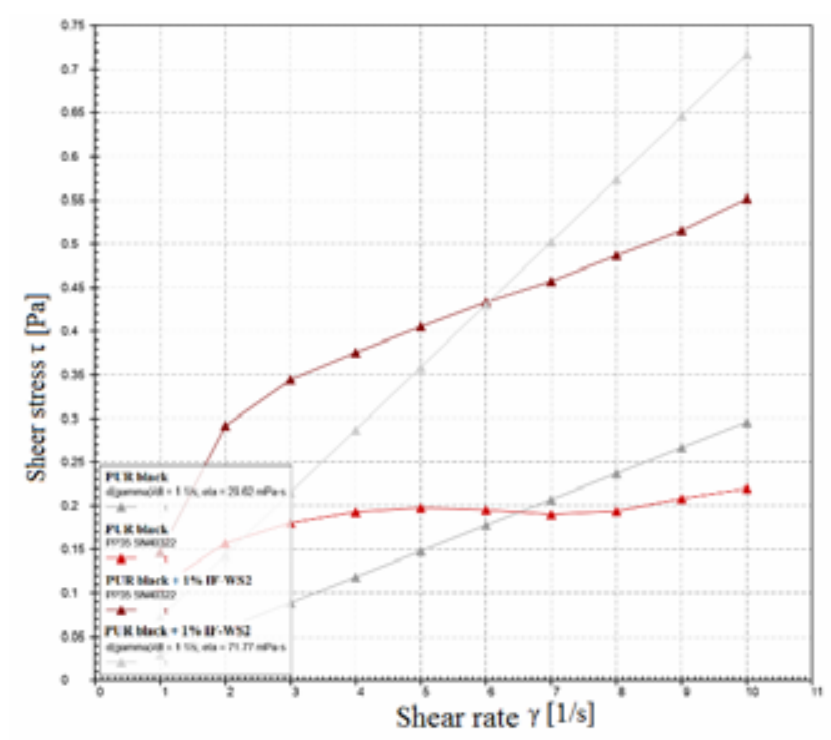

Figure 7. Sheer stress - shear rate dependence for PUR black

The results indicate that an addition of IF-WS2 nanoparticles has an impact on the paints rheology - viscosity of the paint gets higher: paint without nanoparticles has viscosity $n=29.62 \mathrm{mPa} \cdot \mathrm{s}$, and the paint containing $1 \mathrm{wt} . \%$ of IF-WS 2 has viscosity $n=71.77$ $\mathrm{mPa} \cdot \mathrm{s}$. It is expected that after dispersing submicron or nanosized materials into a polymer, its melt / dissolved viscosity will increase. This is due to the fact that the dispersion is accompanied by adsorption of a monolayer consisting of the polymer matrix. The specific surface area increases generally in reversal proportion to the particle size. In the above-mentioned case, when the particle of $1 \mathrm{~cm}$ is micronized to $10 \mathrm{~nm}$, the specific surface area increases million times. As the increase in the specific surface area directly influences such properties as the solubility and reaction rates of the particles [26], incorporation of nanofillers in thermoplastics is generally associated to the significant increase in the melt viscosity, at least in the range of low frequencies [27]. Smaller the size of the particle, the greater the viscosity of the system [28].

\section{IR reflection and colorimetric results}

Figures 8 and 9 show dependency graphs for diffuse reflection as the function of wavelength in the area of $650-1000 \mathrm{~nm}$ for the tested black and dark green tone, with and without nanoparticles.

According to the Serbian military standard for values of diffuse reflection in the visible-near infra-red region for the black and dark green tone, SORS 7511/11 [29], all of the dyed samples have good and acceptable camouflage behaviour in the given area of electromagnetic spectrum. Moreover, the greater the reflectance value the better camouflage protection is, so in these 
terms for black tone, we would suggest usage of dye with nanoparticles. As seen in Fig.8, there is a difference in the reflectance curve behaviour in the $800-950 \mathrm{~nm}$ wavelength area. This finding demands further physical and chemical analysis. Nevertheless, dye in which nanoparticles are added shows more uniformity in the given electromagnetic spectrum area and therefore we have another reason to believe that its application in camouflage protection could be beneficial.

Contrary to the results for the black tone, as seen in Fig.9, there is no significant difference in the reflectance curve behavior for dark green tone regarding both types of dyes (with or without nanoparticles). Sample with nanoparticles shows less uniformity in the $800-950 \mathrm{~nm}$ wavelength area and the reflectance curve shows slightly greater values than the sample without nanoparticles. Both samples have a small maximum around 850 $\mathrm{nm}$ while sample with nanoparticles also has a minimum around $860 \mathrm{~nm}$. These findings demand further physical and chemical analysis.

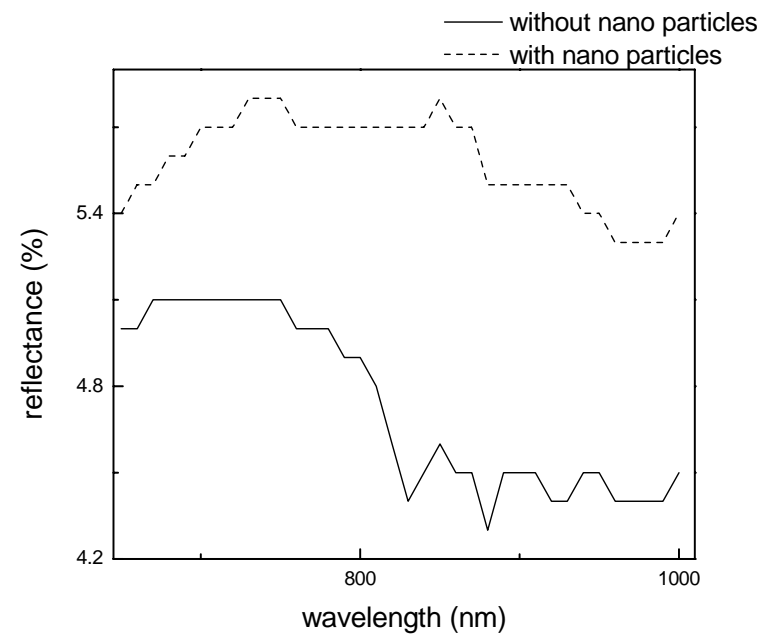

Figure 8. Dependency graph for diffuse reflection in the range between 650$1000 \mathrm{~nm}$ for the PUR black (with and without nanoparticles)

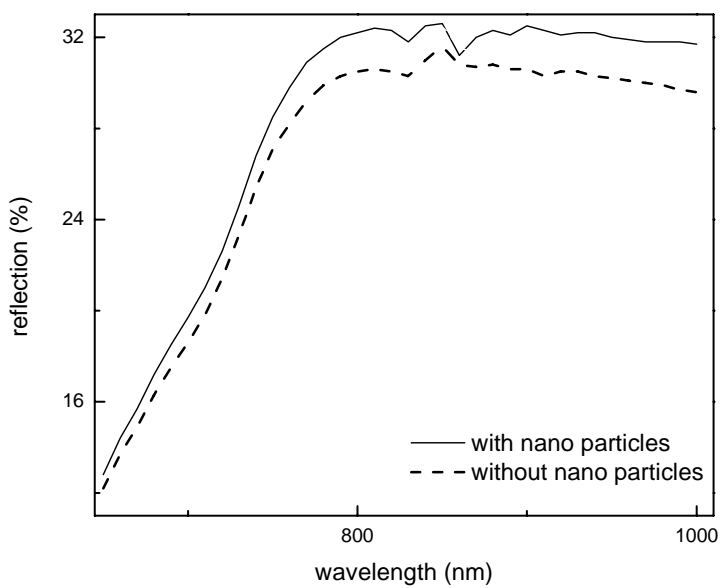

Figure 9. Dependency graph for diffuse reflection in the range between 650$1000 \mathrm{~nm}$ for the PUR dark green (with and without nanoparticles)

In these terms another test has been performed and color coordinates have been measured. The results are presented in Table 3 .

Table 3. Colour coordinates defined in CIE system for both samples

\begin{tabular}{|c|c|c|c|c|c|c||}
\hline & \multicolumn{3}{|c|}{ PUR black } & \multicolumn{3}{c|}{ PUR dark green } \\
\hline \hline Color coordinates & $\mathrm{L}^{*}$ & $\mathrm{a}^{*}$ & $\mathrm{~b}^{*}$ & $\mathrm{~L}^{*}$ & $\mathrm{a}^{*}$ & $\mathrm{~b}^{*}$ \\
\hline With nanoparticles & 27.09 & 0.48 & 0.11 & 39.09 & -5.74 & 10.86 \\
\hline Without nanoparticles & 26.28 & 0.40 & 0.10 & 38.86 & -5.96 & 10.86 \\
\hline
\end{tabular}

The main characteristic these data provide is so called $\Delta \mathrm{E}$ difference which is a number calculated from the equation (1):

$$
\Delta E=\sqrt{\Delta L^{* 2}+\Delta a^{* 2}+\Delta b^{* 2}}
$$

where $\Delta L^{*}, \Delta a^{*}$ and $\Delta b^{*}$ are differences between two given coordinates values. If the $\Delta E$ is less than 1 , the difference between two paints is not visible to the observer's eye.

In our case $\Delta E=0.81$ for black tone and $\Delta E=0.32$ for dark green tone. So, the observer's eye cannot see the difference between two black tone samples neither for two dark green samples.

To summarize, black tone with nanoparticles addition, as well as the dark green tone have better diffuse reflectance and the difference between the two samples is not visible to the observer's eye. Therefore, these results give us a reason to proceed with the examination and characterization of this type of nano modified paints.

\section{Conclusion}

Physical-mechanical properties of the polymeric coating used for military camouflage purposes were enhanced by adding IF-WS $\mathrm{W}_{2}$ nanoparticles in a small concentration ( $1 \mathrm{wt} . \%$ and $0.5 \mathrm{wt} . \%$ ). The hardness and the resistance to steel balls impact were improved for the samples with nanoparticles comparing to the sample without them. The adherence, elasticity and flexibility of both samples have met the requirements of the relevant military standards: the rheological behavior is in accordance with the expectations, while the abrasion resistance of both samples failed the test. However, abrasion resistance is significantly better for the sample containing nanoparticles of IF-WS 2 .

Both tested samples have met the criteria of the tests - the coatings are persistent in all the used aggressive media: water, salt water, mineral oil and a mixture of isooctane and benzene.

Rheological behavior of paints with nanofiller addition has shown, as expected, that viscosity increases with shear rate for the samples with nanoparticles.

Spectrophotometric examinations indicate that dyes with nanoparticles addition have better camouflage qualities and the difference between each pair of samples is not visible to the observer's eye. These obtained and presented results encourage application of IF-WS $\mathrm{W}_{2}$ as nanofiller in order to improve military paints resistance and general properties. These findings, also, give us a reason to proceed with the examination and characterization of coatings with IF-WS $\mathrm{W}_{2}$. Having in mind that very good results have been obtained with low nanoparticles concentrations used in this presented research, it would be interesting to examine the possibility of using even lower concentrations of nanofiller, in order to achieve improved mechanical properties and to retain, or even improve, the required camouflage properties.

\section{Acknowledgement}

The authors thank to the Ministry of Education, Science and Technological Development of the Republic of Serbia for the financial support of the research through the TR 34034 project (2010-2017 - "Application of nanomaterials in the improvement of respiratory and percutaneous protection under conditions of ecological imbalance caused by radioactive, chemical and biological contamination"). The authors also thank to PITURA Company, Belgrade. 


\section{References}

[1] MATHIAZHAGAN,A., JOSEPH,R.: Nanotechnology-A New Prospective in Organic Coating - Review, International Journal of Chemical Engineering and Applications, 2011, Vol.2, No.4, pp.225-237.

[2] WILSON,M., KANNANGARA,K.: Nanotechnology-basic science and emerging technologies, Overseas press India pvt Ltd New Delhi.

[3] GARCÍA-LECINA,E., GARCÍA-URRUTIA,I., DÍEZ,J.A., FORNELL,J., PELLICER,E., SORT,J.: Codeposition of inorganic fullerene-like $\mathrm{WS}_{2}$ nanoparticles in an electrodeposited nickel matrix under the influence of ultrasonic agitation, Electrochimica Acta, 2013, 114 , pp.859- 867 .

[4] SHAHAR,C., ZBAIDA,D., RAPOPORT,L., COHEN,H., BENDIKOV,T., TANNOUS,J., DASSENOY,F., TENNE,R.: Surface Functionalization of $\mathrm{WS}_{2}$ Fullerene-like Nanoparticles, Langmuir, 2010, 26(6), pp.4409-4414 DOI: 10.1021/la903459t.

[5] TENNE,R., MARGULIS,L., GENUT,M., HODES,G.: Polyhedral and Cylindrical Structures of Tungsten Disulfide, Nature, 1992, 360, pp.444-446.

[6] TEVET,O.: Mechanical and tribological properties of inorganic fullerene-like (IF) nanoparticles, Weizmann Institute of science, Rehovot, Israel, 2011.

[7] TEVET,O., VON-HUTH,P., $\quad$ POPOVITZ-BIRO,R., ROSENTSVEIG,R., WAGNER,H.D., TENNE,R.: Friction mechanism of individual multilayered nanoparticles, Proc. Natl. Acad. Sci. U.S.A., 2011, 108, pp.19901-19906.

[8] XU,F.: Large Scale Manufacturing of IF-WS ${ }_{2}$ Nanomaterials and Their Application in Polymer Nanocomposites, University of Exeter, Devon, UK, 2013.

[9] LI,H., YIN,Z., JIANG,D., HUO,Y., CUI,Y.: Tribological behavior of hybrid PTFE/Kevlar fabric composites with nano-Si3N4 and submicron size $W_{2}$ fillers, Tribol. Int. 2014, 80, pp.172-178.

[10] ZHU,Y.Q., SEKINE,T., KIEREN,B.S., FIRTH,S., TENNE,R., ROSENTSVEIG,R., KROTO,H.W., WALTON,D.R.: Shock-Wave Resistance of $W_{2}{ }_{2}$ Nanotubes, J. Am. Chem. Soc. 2003, 125, pp.1329-1330.

[11] NEMES,P.I.: Nanocomposite coatings for anticorrosion protection of some metals, PhD Thesis, Universitatea Babeş-Bolyai, Cluj Napoca, 2013.

[12] EIDELMAN,O., FRIEDMAN,H., ROSENTSVEIG,R., MOSHKOVITH,A. PERFILIEV,V., COHEN,S. R. FELDMAN,Y., RAPOPORT,L., TENNE,R.: Chromium-rich coatings with $\mathrm{WS}_{2}$ nanoparticles containing fullerenelike structure, NANO: Brief Reports and Reviews, 2011, Vol.6, No.4, pp.313-324, DOI: 10.1142/S1793292011002755
[13] HU,X. G., CAI,W.J., XU,Y.F., WAN,J.C., SUN,X.J.: Electroless Ni$P$-(nano-MoS2) composite coatings and their corrosion properties, Surface Engineering 2009, Vol.25, No.5, pp.361-366, DOI: 10.1179/174329408X282532

[14] DE MEYER,T., STEYAERT,I., HEMELSOET,K., HOOGENBOOM,R, VAN SPEYBROECK,V., DE CLERCK,K. Halochromic properties of sulfonphthaleine dyes in a textile environment: The influence of substituents, Dyes and Pigments, 2016, 124, pp.249-257.

[15] GULMINI,M., IDONE,A., DIANA,E., GASTALDI,D., VAUDAN,D., ACETO,M.: Identification of dye stuffs in historical textiles: Strong and weak points of a non-invasive approach, Dyes and Pigments, 2013, 98 pp.136-145.

[16] WAKE,L.V., BRADY,R.F.: Formulating infrared coatings for defence applications, MRL-RR-1 -93, Materials Research Laboratory DSTO, Australia, 1993.

[17] SORS 1564

[18] SORS 9404/15

[19] SORS 1634/03

[20] SRPS EN ISO 2409

[21] SRPS EN ISO 1520

[22] SRPS EN ISO 1519

[23] JUS T.P.9

[24] Anton Paar Germany GmbH, MCR: The Modular Compact Rheometer Series, 2016

[25] Shimadzu, UV 3600 Tutorial, 2009.

[26] NAITO,M., HOSOKAWA,M., YOKOYAMA,T., NOGI,K.: Nanoparticle Technology Handbook, Elsevier, 2007.

[27] PEDRAZZOLI,D.: Understanding the effect of nanofillers on the properties of polypropylene and glass fiber/polypropylene multiscale composites, Doctoral thesis, Department of Industrial Engineering, University of Trento, Italy, 2014.

[28] REYNAUD,E.: Nanofillers in polymeric matrix: a study on silica reinforced PA6, Polymer, 2001, 42, p.8759.

[29] SORS 7511/11.

\title{
Svojstva standardnog polimernog i vodorazredivog premaza za vojnu maskirnu zaštitu sa dodatkom neorganskih fulerenskih nanočestica volfram disulfida (IF-WS ( $_{2}$
}

\begin{abstract}
Istraživana je mogućnost poboljšanja svojstava standardnog polimernog i vodorazredivog premaza za vojnu maskirnu zaštitu dodatkom neorganskih fulerenskih nanočestica volfram-disulfida, IF-WS 2 . Nanočestice su dodate i u boji dispergovane ultrazvučno. Boje su nanešene na standardne čelične pločice, nakon toga osušene, u cilju ispitivanja hemijske otpornosti na agresivne medije i sledećih fizičko-mehaničkih karakteristika: tvrdoća, savitljivost, elastičnost, otpornost na abraziju, otpornost na udar kuglica i prianjanje. Ova svojstva su poređena za boje bez i sa dodatkom IF-WS 2 nanočestica. Uticaj dodatka IF-WS 2 na reološka svojstva ispitivanih boja praćen je pomoću Dinamičkog Mehaničkog Analizatora (DMA), posmatrajući promenu viskoziteta u funkciji od brzine smicanja. Takođe, ispitivane su i maskirne karakteristike-infracrvena refleksija i kolorimetrija. Postignuta su značajna poboljšanja tvrdoće, mehaničke otpornosti na udar čeličnih kuglica i abraziju.
\end{abstract}

Ključne reči: premazi, zaštitni premazi, polimerni premazi, vodorazredivi premazi, volfram disulfid, nanočestice, maskiranje, maskirna sredstva, vojna primena. 


\title{
Свойства стандартных полимерных и водосодержащих покрытий для военной защиты камуфляжа с добавлением неорганические фулереноподобные наночастиц вольфрама дисульфида (IF-WS $)$
}

\begin{abstract}
Изучена возможность улучшения свойств стандартного полимерного покрытия и покрытия на водной основе для защиты военной маскировки путём добавления неорганических наночастиц фуллеренов дисульфида вольфрама IF$\mathrm{WS}_{2}$. Наночастицы добавляли и диспергировали в краске ультразвуковым облучением. Краски наносят на стандартные стальные пластины и высушивают для изучения химической стойкости к агрессивным средам и следующих физико-механических свойств: твёрдости, гибкости, эластичности, стойкости к истиранию, устойчивости к ударам стальных шариков и клейкости. Эти свойства сравнивались для красок без наночастиц и с наночастицами IF-WS 2 . Эффект добавления IF-WS 2 на реологические свойства исследованных красок был исследован с использованием динамического механического анализатора (ДМА), наблюдая изменение вязкости в зависимости от скорости сдвига. Были также изучены свойства маскировки - ИК-отражение и колориметрия. Достигнуты значительные улучшения, механической стойкости к истиранию и ударам стальных шариков, а также твёрдости.
\end{abstract}

Ключевые слова: покрытия, защитные покрытия, полимерные покрытия, покрытия на водной основе, дисульфид вольфрама, наночастицы, маскирование, маскирующие агенты, военные применения.

\section{Propriétés de revêtements standards polymeriques et à base d'eau pour la protection de camouflage militaire avec addition de nanoparticules de disulfure de tungstène de type fullerène inorganique (IF-WS $\left.\mathbf{S}_{2}\right)$}

\begin{abstract}
La possibilité d'améliorer les propriétés d'un revêtement polymère standard et d'un revêtement à base d'eau pour la protection militaire en ajoutant les nano particules IF-WS 2 a été examinée. Les nano particules ont été ajoutées et dispersées dans la peinture par l'irradiation de l'ultrason. Les peintures ont été appliquées aux plaques d'acier standard et ensuite séchées pour les examens de la résistance chimique aux milieux agressifs ainsi que pour les examens des propriétés physique et mécanique suivantes: dureté, flexibilité, élasticité, résistance à l'abrasion, résistance à l'impact des billes d'acier et l'adhérence. Ces propriétés ont été comparées pour la peinture sans ou avec les nano particules IF-WS 2 . L'effet de l'ajout de IF-WS 2 sur les propriétés rhéologiques des peintures examinées a été suivi à l'aide de l'Analyseur dynamique mécanique (DMA) en observant le changement de viscosité en fonction de la vitesse de cisaillement. On a examiné aussi les caractéristiques de camouflage - réflexion infrarouge et colorimétrie. On a réalisé les améliorations significatives de la dureté, de la résistance mécanique à l'impact des billes d'acier et à l'abrasion.
\end{abstract}

Mots clés: revêtement, revêtement de protection, revêtements polymères, revêtements à base d'eau, bisulfure de tungstène, nano particules, camouflage, moyens de camouflage, utilisation militaire. 